\title{
ANALISIS PEMILIHAN JASA FORWARDER DENGAN MENGGUNAKAN METODE ANALYTICAL HIERARCHY PROCESS (AHP) DI PT. XYZ
}

\author{
Ambar Wulan ${ }^{1}$ ) Bambang Hendrawan ${ }^{2}$ ) \\ 1) Prodi Administrasi Bisnis Terapan Politeknik Negeri Batam, email: vivavirgo@yahoo.com \\ 2) Prodi Administrasi Bisnis Terapan Politeknik Negeri Batam, email: benks@ polibatam.ac.id
}

\begin{abstract}
Choosing a good and quality forwarder is something that cannot be considered easy. Errors in choosing a forwarding service will hinder the operational processes of a company, especially if the company is an international scale such as PT. XYZ. This study aims to choose the best forwarder services for the company. Criteria set by PT. XYZ in choosing forwarder services, namely Cost, Quality, Delivery, and Responsiveness. In this research forwarders who offer themselves or take part in bidding to work with PT. XYZ has only 4, namely forwarder A, forwarder B, forwarder C, and forwarder D. In this study the author uses the Analytical Hierarchy Process (AHP) method to determine which forwarder fits the company's criteria. The most important criteria for PT. XYZ is a Cost with the highest weight of 0.4841, Quality criteria with 0.2310 , Delivery criteria with 0.1676 and Responsiveness criteria with 0.1171. then followed by forwarder A with the highest weight of 0.535, then forwarder $B$ with 0.202, forwarder C with 0.145, and forwarder D with 0.119 .
\end{abstract}

Keyword: Analytical Hierarchy Process (AHP), Selection of Forwarder Services.

\begin{abstract}
Abstrak
Memilih jasa forwarder yang baik dan berkualitas adalah sesuatu yang tidak bisa dianggap mudah. Kesalahan dalam memilih jasa forwarderakan menghambat proses operasional suatu perusahaan, terlebih jika perusahaan tersebut berskala Internasional seperti PT. XYZ. Penelitian ini bertujuan untuk memilih jasa forwarder yang terbaik untuk perusahaan. Kriteria yang ditetapkan oleh PT. XYZ dalam memilih jasa forwarder yaitu Cost, Quality, Delivery, dan Responsiveness. Pada penelitian ini forwarder-forwarder yang menawarkan diri atau mengikuti bidding untuk bekerja sama dengan PT. XYZ hanya ada 4, yaitu forwarder A, forwarder B, forwarder C, dan forwarder D. Dalam penelitian ini penulis menggunakan metode Analytical Hierarchy Process (AHP) untuk menentukan forwarder mana yang sesuai kriteria perusahaan. Kriteria yang paling penting bagi PT. XYZ adalah Cost dengan bobot tertinggi sebesar 0.4841, kriteria Quality dengan 0.2310 , kriteria Delivery dengan 0.1676 dan kriteria Responsiveness dengan 0.1171. lalu diikuti dengan forwarder A dengan bobot tertinggi sebesar 0.535, lalu forwarder B dengan 0.202, forwarder C dengan 0.145, dan forwarder D dengan 0.119.
\end{abstract}

Kata kunci: Analytical Hierarchy Process (AHP), Pemilihan Jasa Forwarder. 


\section{PENDAHULUAN}

Semua perusahaan pada umumnya tentu ingin unggul dalam berkompetisi didunia bisnis. Dalam berkompetisi, suatu perusahaan harus meningkatkan daya saing melalui penyesuaian produk yang berkualitas, pengurangan biaya, dan ketepatan waktu pengiriman. Untuk memenuhi permintaan konsumen akan produk yang berkualitas, ada beberapa faktor yang terlibat didalamnya, yaitu penyuplai bahan baku/material, pihak distributor, sumber daya yang memadai, dan tentunya suatu sistem yang bisa mengendalikan itu semua.

Manajemen rantai pasokan atau juga dikenal dengan sebutan Supply Chain Management (SCM) adalah sistem yang mengatur dan mengontrol proses produksi,

pengiriman bahan baku/material, penyimpanan, proses manufaktur, ditribusi produk dan penjualan produk hingga sampai

ketangan konsumen. Pengadaan dan pengiriman bahan baku sendiri tidak lepas dari jasa forwarder sebagai perantara antara supplier dan perusahaan, dan oleh sebab itu pada tahap ini perusahaan dihadapkan pada pemilihan jasa forwarder yang sesuai kriteria perusahaan.

Saat ini PT. XYZ memiliki beberapa jasa forwarder untuk memasok material dengan beberapa kriteria, diantaranya biaya yang yang ditawarkan (cost), kualitas yang ditawarkan (quality), servis pengantaran yang dijanjikan (delivery), dan respon cepat yang diberikan (responsiveness). Kesalahan dalam pemilihan jasa forwarderakan berdampak pada produktivitas dan operasional PT. XYZ.

Banyak metode yang dapat digunakan dalam pengambilan keputusan memilih dari beberapa pilihan dengan kriteria tersendiri, salah satunya adalah Analytical Hierarchy Process (AHP).

Dari uraian latar belakang diatas, maka penulis tertarik untuk melakukan penelitian dengan judul "Analisis Pemilihan Jasa

\section{ForwarderDengan}

\section{Menggunakan Metode Analytical Hierarchy Process (AHP) di PT. XYZ".}

Tujuan dari penelitian ini adalah untuk melakukan pemilihan jasa forwarder yang tepat dengan menggunakan metode Analytical Hierarchy Process (AHP).
Manfaat yang diharapkan dari penelitian ini adalah :

1. Manfaat Praktis

Bagi perusahaan, penelitian ini diharapkan mampu memberi masukan kepada perusahaan dalam melilih jasa forwarder yang tepat menggunakan metode Analytical Hierarchy Process (AHP).

2. Manfaat Teoritis

a. Bagipembaca,penelitianini diharapkan dapat menambah pengetahuan dan referensi pembaca tentang metode Analytical Hierarchy Process (AHP).

b. Bagi penulis, penelitian ini diharapkan menambah wawasan penulis tentang kebijakan pengambilan keputusan menggunakan Metode Analytical Hierarchy Process (AHP).

\section{KAJIAN PUSTAKA}

\section{Kajian Teori}

Beberapa penelitian terdahulu terkait Analytical Hierarchy Process (AHP) :

1. Jannah Miftakhul, Muhammad Fakhry, dan Rahmawati tahun 2011 (Pengambilan Keputusan Untuk Pemilihan Supplier Bahan Baku Dengan Pendekatan Analytic Hierarchy Process Di PR Pahala Sidoarjo), dengan hasil sebagai berikut:

a. Hasil rancangan dengan menggunakan model Quality, Cost, Deliver, Flexibility, Responsiveness (QCDFR) menghasilkan $11 \quad$ Supplier Performance Indicator (indikator kinerja supplier) yaitu : tiga indikator untuk kriteria cost, dua indikator untuk kriteria delivery, dua indikator untuk kriteria flexibility, dan duan indikator untuk kriteria responsiveness

b. Faktor kriteria palingmemberikan kontribusi terhadap pemilihan supplier di PR Pahala adalah kriteria quality memiliki bobot sebesar 0,373 selanjutnya diikuti oleh cost 0,266 , Responsiveness sebesar 0,156, kriteria delivery sebesar 0,128, dan kriteria flexibility sebesar 0,077. Kriteria dengan bobot yang paling besar adalah kriteria yang paling penting.

c. Alternatif pemilihan supplier yang tepat bagi perusahaan adlah (daerah Madura 0,311, Tulungagung 0,234, 
Ambar Wulan \& Bambang, analisis pemilihan jasa forwarder dengan menggunakan metode ...

Bondowoso 0,253, Malang 0,202). Supplier dengan bobot yang paling besar adalah supplier terbaik.

2. Tominanto tahun 2012 (Sistem Pendukung Keputusan Dengan Metode Analytical

Hierarchy Process (AHP) Untuk Penentuan Prestasi Kinerja Dokter Pada RSUD. Sukoharjo), dengan hasil sebagai berikut :

a. Dari hasil pengujian terhadap sistem yang dikembangkan menggunakan metode AHP dapat disimpulkan bahwa sistem telah berjalan dengan benar, sehingga sistem ini dapat digunakan pimpinan sebagai dasar pengambilan keputusan dalam menentukan prestasi kinerja dokter pada instansinya.

b. Sistem yang telah di kembangkan dengan metode AHP ini, dapat digunakan dengan jumlah faktor kriteria yang ditentukan oleh user sendiri, sehingga dapat disesuaikan dengan kebutuhan.

c. Tidak bisa dipungkiri bahwa sistem pendukung keputusan ini belum sepenuhnya bersifat obyektif karena input manusia masih berperan besar, namun diharapkan dengan adanya sistem ini proses penentuan prestasi kinerja dokter dapat lebih obyektif jika dibandingkan dengan cara manual sebelumnya.

3. Siti Wardah tahun 2013 (Model Pemilihan Pemasok Bahan Baku Kelapa Parut Kering Dengan Metode AHP (Studi Kasus PT. Kokonako Indonesia)), dengan hasil sebagai berikut :

a. Pada pengembangan model pemilihan pemasok digunakan metode Analytic Hierarchy Process (AHP) karena kompleksnya pasokan bahan baku kelapa parut kering oleh pemasok untuk ketersediaan bahan baku yang berdiameter $\geq 10 \mathrm{~cm}$ dan sesuai kuantitas bahan baku kelapa parut kering.

b. Pada model pemilihan pemasok dihasilkan alternatif pemasok adalah Kecamatan Tempuling.

c. Berdasarkan hasil verifikasi dan validasi bahwa model pemilihan pemasok yang dihasilkan verified dan valid.
4. Desty Kasmawaty tahun 2015 (Evaluasi Kinerja Supplier Dengan Menggunakan Metode Analytical Hirarchy Process (AHP)), dengan hasil sebagai berikut :

a. Sebelum melakukan evaluasi, perusahaan telah menetapkan kriteria guna membantu dalam penilaian kinerja supplier tersebut, adapun kriteria tersebut terdiri dari price, delivery, quality, service, dengan ketetapan bahwa kriteria price merupakan kriteria utama untuk penilaian evaluasi kinerja ini dengan bobot 0,4547 . Kemudian delivery yang memiliki rank kedua dengan bobot 0,3205. Quality dengan rank ketiga memiliki bobot 0,1394 dan kriteria service yang memiliki rank keempat dengan bobot terendah 0,0855.

b. Hasil dari pembobotan kriteria evaluasi supplier tersebut menentukan bobot global prioritas dari setiap bobot sub-sub kriteria. Hal ini dapat dilihat dari sub-sub kriteria price memiliki bobot global prioritas keselruhan 45,4\% lebih tinggi dari bobot global lainnya yang mana untuk delivery hanya $32 \%$, quality $14 \%$ dan service dengan bobot global $8,6 \%$ sesuai dengan bobot keempat kriteria evaluasi yang telah dilakukan sebelumnya.

c. Hasil dari perhitungan alternatif supplier didapatkan bahwa supplier PT. I memiliki bobot tertinggi dengan bobot 0,323 dari bobot tersebut dapat disimpulkan bahwa supplier PT. I memiliki kinerja yang baik dalam hal memasok bahan baku bagi perusahaan. Supplier G memiliki bobot 0,262 dengan kesimpulan bahwa supplier PT. G mampu menjadi supplier terbaik bagi perusahaan, sedangkan supplier dengan bobot kinerja terendah ialah supplier PT. B dan PT. E dengan bobot 0,207 dan 0,208 dengan selisih $1 \%$ ini menunjukkan bahwa kedua supplier tersebut belum memberikan kinerja yang terbaik bagi perusahaan. 


\section{Pengertian Jasa}

Dalam Sugiarto (2002), jasa merupakan layanan seseorang/instansi/barang yang akan memenuhi kebutuhan masyarakat.

Kotler dan Keller dalam Yuliana (2012)mengatakan bahwa perusahaan harus mempertimbangkan empat karakteristik jasa yaitu :

\section{Intangibility (tidak berwujudnya jasa)}

Jasa adalah perbuatan atau usaha. Jasa bersifat tidak nyata dalam arti tidak dapat disentuh, dilihat atau dirasakan sampai saat konsumsi.

2. Inseparability (ketidakterpisahan jasa).

Maksudnya adalah jasa tidak dapat dipisahkan dari penyedianya, karena pelanggan turut hadir saat jasa itu diproduksi, interaksi penyedia jasa pelanggan merupakan sifat khusus dari pemasaran jasa. Baik penyedia jasa maupun pelanggan akan mempengaruhi hasil jasa.

3. Variability (Keragaman jasa).

Kualitas jasa sangat bervariasi tergantung dari siapa yang memberikan, kapan dan dimana diberikan.

4. Perishability (tidak tahan lama)

Suatu jasa tidak dapat disimpan untuk penjualan atau pemakaian yang akan datang. Oleh karena itu perusahaan jasa seringkali merancang strategi agar lebih baik menyesuaikan permintaan dan penawarannya.

\section{Pengertian Forwarder}

Rajasekar dan Prabhakar (2015)Multifaceted activities of Freight Forwarders :

\section{A advisor \& consultant}

2. As a transporter

3. As a warehouse agent

Dalam Siswosoediro (2008), Freight forwarding adalah usaha yang ditujukan mewakili kepentingan pemilik barang untuk mengurus semua kegiatan yang diperlukan bagi terlaksananya pengiriman dan penerimaan barang melalui transportasi darat, laut dan udara. Pemberian izin usaha jasa pengurusan transportasi (IUJPT) atau forwarding biasanya dikeluarkan kantor dinas perhubungan

kota/provinsi yang diberikan kepada perusahaan untuk kegiatan usaha jasa transpotasi di Indonesia.

Usaha ini memiliki lingkup kegiatan yang ditujukan untuk mewakili kepentingan pemilik barang untun mengurus kegiatan yang diperlukan bagi terlaksananya pengiriman barang melalui transportasi darat, laut atau udara yang mencakup kegiatan penerimaan, penyimpanan, sortasi, pengepakan, penandaan, pengukuran, penimbangan, pengurusan, penerbitan dokumen angkutan, dan perhitungan biaya angkutan. Selain itu, usaha ini juga menangani klaim asuransi atas pengiriman barang serta penyelesaian tagihan dan biaya-biaya lainnya berkenaan dengan pengiriman barang-barang tersebut sampai diterimanya barang oleh pihak yang berhak menerimanya.

\section{Pengertian Analytical Hierarchy Process (AHP)}

It is a framework of logic and problem-solving that spansthe spectrum finstant awareness to fully integrated onsiousness by organizing pereptions, feelings, judgements and memories into hierarchy of fores that influene decision results. The AHP is based on the innate human ability to use information and experience to estimate relative magnitudes through paired comparisons. These comparisons areused to contruct ratio scales on a variety of dimensions both tangible and intangible (Saaty, 2000).

Pengertian diatas dapat diartikan sebagai berikut"Analytical Hierarchy Process (AHP) adalah kerangka logika dan pemecahan masalah yang membentang spektrum dari

kesadaran instan untuk sepenuhnya terintegritasi kesadaran dengan mengorganisir persepsi, perasaan, penilaian, dan kenangan dalam hierarki kekuatan yang mempengaruhi hasil keputusan. AHP didasarkan pada

kemampuan bawaan manusia untuk menggunakan informasi dan pengalaman untuk memperkirakan besaran relatif melalui perbandingan berpasangan, perbandingan ini digunakan untuk membangun skala rasio pada berbagai dimensi baik berwujud dan tidak berwujud".

Saaty dalam Tominanto (2012), AHP dikembangkan DR. Thomas L. Saaty dari Wharton School of Business pada tahun 1970an untuk mengorganisasikan informasi dan judgement dalam memiliki alternatif yang paling disukai. Pada dasarnya AHP adalah adalah metode untuk memecahkan suatu masalah yang komplek dan tidak terstruktur kedalam kelompoknya, mengatur kelompok- 
Ambar Wulan \& Bambang, analisis pemilihan jasa forwarder dengan menggunakan metode ... yaitu :

kelompok tersebut kedalam suatu susunan hierarki, memasukkan nilai numerik sebagai pengganti persepsi manusia dalam melakukan perbandingan relatif dan akhirnya dengan suatu sintesis ditentukan elemen yang mempunyai prioritas tertinggi.

\section{METODE PENELITIAN}

Jenis penelitian ini adalah penelitian kualitatif. Dalam penelitian kualtitatif tidak menggunakan istilah populasi, tetapi oleh Sradley dinamakan "social situation" atau situasi sosial yang terdiri atas 3 elemen yaitu : tempat (place), pelaku (actors), dan aktivitas (activity) yang berinteraksi secara sinergis (Sugiyono, 2015).

Sampel dalam penelitian kualitatif bukan dinamakan responden, tetapi sebagai narasumber, atau partisipan, informan, teman, dan guru dalam penelitian. Informan dalam penelitian ini adalah seluruh karyawan Departement Purchasing yang berjumlah 6 orang, seluruh karyawan Departement Logistic yang berjumlah 3 orang, dan user pengguna material (direct dan indirect) berjumlah 2 orang. Jadi total informan penelitian ini adalah 11 orang.

\section{Metode Analisis Data}

Dalam penelitian kali ini, penulis menggunakan metode analisis data yng digunakan adalah Statistik Deskriptif. Menurut Wibowo (2012), statistik deskriptif adalah statistik yang menjelaskan suatu data telah dikumpulkan dan diringkas pada aspek-aspek penting berkaitan dengan data tersebut.

Biasanya meliputi gambaran atau mendeskripsikan hal-hal sebagai berikut dari suatu data :

Mean, Median, Modus, Range, Varian, Frekuensi, Nilai maksimum, Nilai minimum, dan Standart deviasi.

Untuk menghitung ke-9 kategori tersebut, penulis menggunakan aplikasi databasis Microsoft Excel untuk menghitung rumusnya. Sedangkan untuk perhitungan.

Metode Analytical Hierarchy Process (AHP) penulis menggunakan aplikasi Expert Choice v.11.

Dalam Goodwin, ada 5 ikhtisar dari AHP,
Stage 1: Set Up The Decision Hierarcy

atau mengatur hirarki keputusan.

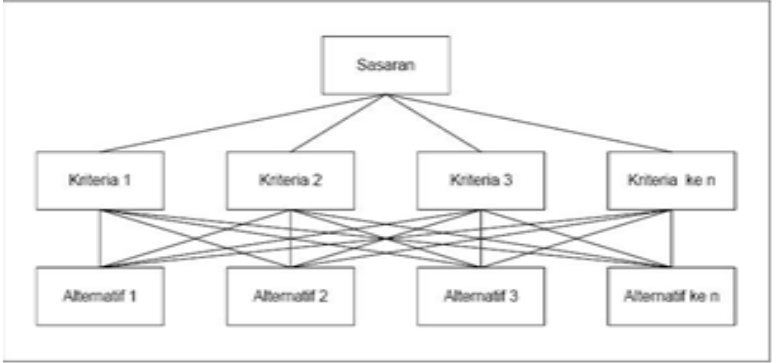

Gambar 1. Struktur Hirarki

Sumber : Wardah (2013)

Stage 2 : Make pairwise comparisons of attributes and alternatives atau membuat matrik perbandingan berpasangan dari atribut (kriteria) dan alternatif (sub-kriteria).

Tabel 1. Contoh Matriks Bepasangan Antar

Kriteria

\begin{tabular}{|c|c|c|c|c|}
\hline Cost & Cost & Quality & Delivery & $\begin{array}{c}\text { Responsive } \\
\text { ness }\end{array}$ \\
\hline Quality & $\begin{array}{c}\text { (isi dengan } \\
\text { skala) }\end{array}$ & $\begin{array}{c}\text { (isi dengan } \\
\text { skala) }\end{array}$ & $\begin{array}{c}\text { (isi dengan } \\
\text { skala) }\end{array}$ & $\begin{array}{c}\text { (isi dengan } \\
\text { skala) }\end{array}$ \\
\hline Delivery & $\begin{array}{c}\text { (isi dengan } \\
\text { skala) }\end{array}$ & $\begin{array}{c}\text { (isi dengan } \\
\text { skala) }\end{array}$ & $\begin{array}{c}\text { (isi dengan } \\
\text { skala) }\end{array}$ & $\begin{array}{c}\text { (isi dengan } \\
\text { skala) }\end{array}$ \\
\hline $\begin{array}{c}\text { Responsive } \\
\text { ness }\end{array}$ & $\begin{array}{c}\text { (isi dengan } \\
\text { skala) }\end{array}$ & $\begin{array}{c}\text { (isi dengan } \\
\text { skala) }\end{array}$ & $\begin{array}{c}\text { (isi dengan } \\
\text { skala) }\end{array}$ & 1 \\
\hline
\end{tabular}

Sumber : Konsep yang dikembangkan oleh peneliti berdasarkan Goodwin (2004)

Tabel 2. Contoh Matriks Perbandingan

Berpasangan Antar Forwarder

\begin{tabular}{|c|c|c|c|c|}
\hline & $\begin{array}{c}\text { Forwarder } \\
A\end{array}$ & $\begin{array}{c}\text { Forwarder } \\
B\end{array}$ & $\begin{array}{c}\text { Forwarder } \\
C\end{array}$ & $\begin{array}{c}\text { Forwarder } \\
D\end{array}$ \\
\hline $\begin{array}{c}\text { Forwarder } \\
A\end{array}$ & 1 & $\begin{array}{c}\text { (isi dengan } \\
\text { skala) }\end{array}$ & $\begin{array}{c}\text { (isi dengan } \\
\text { skala) }\end{array}$ & $\begin{array}{c}\text { (isi dengan } \\
\text { skala) }\end{array}$ \\
\hline $\begin{array}{c}\text { Forwarder } \\
B\end{array}$ & $\begin{array}{c}\text { (isi dengan } \\
\text { skala) }\end{array}$ & 1 & $\begin{array}{c}\text { (isi dengan } \\
\text { skala) }\end{array}$ & $\begin{array}{c}\text { (isi dengan } \\
\text { skala) }\end{array}$ \\
\hline $\begin{array}{c}\text { Forwarder } \\
\text { C }\end{array}$ & $\begin{array}{c}\text { (isi dengan } \\
\text { skala) }\end{array}$ & $\begin{array}{c}\text { (isi dengan } \\
\text { skala) }\end{array}$ & 1 & $\begin{array}{c}\text { (isi dengan } \\
\text { skala) }\end{array}$ \\
\hline $\begin{array}{c}\text { Forwarder } \\
D\end{array}$ & $\begin{array}{c}\text { (isi dengan } \\
\text { skala) }\end{array}$ & $\begin{array}{c}\text { (isi dengan } \\
\text { skala) }\end{array}$ & $\begin{array}{c}\text { (isi dengan } \\
\text { skala) }\end{array}$ & 1 \\
\hline
\end{tabular}

Sumber :Konsep yang dikembangkan oleh

peneliti berdasarkan Goodwin (2004)

Stage 3 : Transform the comparisons into weights and check the consistency of the decision maker's comparisons atau mengubah perbandingan dalam bobot dan memeriksa konsistensi perbandingan pembuat keputusan.

Tabel 3. Skala Kuantitatif Dalam Sistem Pendukung Keputusan 
Journal of Applied Business Administration Vol 2, No 2,September 2018, hlm. 294-306

\begin{tabular}{|c|c|c|c|c|}
\hline $\begin{array}{l}\text { Instensity } \\
\text { of } \\
\text { Important }\end{array}$ & Definition & Explanation & & \\
\hline \multicolumn{3}{|c|}{1} & $\begin{array}{l}\text { Equal } \\
\text { Importance }\end{array}$ & $\begin{array}{l}\text { Two } \\
\text { activities } \\
\text { contribute } \\
\text { equally to the } \\
\text { objective }\end{array}$ \\
\hline \multicolumn{3}{|c|}{2} & Weak & \\
\hline \multicolumn{3}{|c|}{3} & $\begin{array}{l}\text { Moderate } \\
\text { Importance }\end{array}$ & $\begin{array}{l}\text { Experience } \\
\text { ang } \\
\text { judgement } \\
\text { slightly favor } \\
\text { one activity } \\
\text { over another }\end{array}$ \\
\hline \multicolumn{3}{|c|}{4} & $\begin{array}{l}\text { Moderate } \\
\text { Plus }\end{array}$ & \\
\hline \multicolumn{3}{|c|}{5} & $\begin{array}{l}\text { Strong } \\
\text { Importance }\end{array}$ & $\begin{array}{l}\text { Experience } \\
\text { and } \\
\text { judgement } \\
\text { strongly } \\
\text { favor one } \\
\text { activity over } \\
\text { another }\end{array}$ \\
\hline \multicolumn{3}{|c|}{6} & Strong Plus & \\
\hline \multicolumn{3}{|c|}{7} & $\begin{array}{l}\text { Very strong } \\
\text { or } \\
\text { Demonstrated } \\
\text { Importance }\end{array}$ & $\begin{array}{l}\text { An activity is } \\
\text { favored very } \\
\text { over } \\
\text { antoher; it's } \\
\text { dominance } \\
\text { demonstrated } \\
\text { in practice }\end{array}$ \\
\hline \multicolumn{3}{|c|}{8} & $\begin{array}{ll}\text { Very, } & \text { very } \\
\text { strong } & \end{array}$ & \\
\hline \multicolumn{3}{|c|}{9} & $\begin{array}{l}\text { Extreme } \\
\text { Importance }\end{array}$ & $\begin{array}{l}\text { The evidance } \\
\text { favoring one } \\
\text { activity over } \\
\text { another is of } \\
\text { the highest } \\
\text { possible } \\
\text { order of } \\
\text { affirmation }\end{array}$ \\
\hline \multicolumn{3}{|c|}{ Reciprocal of above } & $\begin{array}{l}\text { If activity } i \\
\text { has one of the } \\
\text { above } \\
\text { nonzero } \\
\text { number } \\
\text { assigned to it } \\
\text { when } \\
\text { compared } \\
\text { with activity } \\
j \text {, then } j \text { has } \\
\text { the reciprocal } \\
\text { value when } \\
\text { compred with } \\
i\end{array}$ & $\begin{array}{l}\text { A reasonable } \\
\text { assumption }\end{array}$ \\
\hline \multicolumn{3}{|c|}{ Rational } & $\begin{array}{l}\text { Ratios arising } \\
\text { from the scale }\end{array}$ & $\begin{array}{lr}\text { If } & \\
\text { consistency } & \\
\text { were to be } \\
\text { forced } \\
\text { obtaining } & n \\
\text { numerical } & \\
\text { values } & \text { to } \\
\text { span } & \text { the } \\
\end{array}$ \\
\hline
\end{tabular}

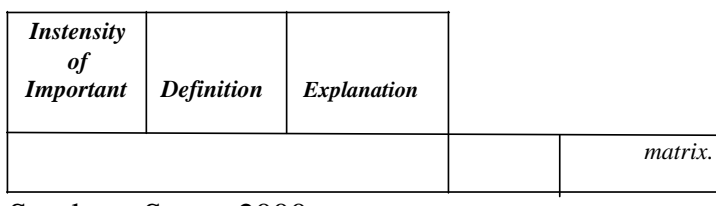

Sumber : Saaty, 2000

Stage 4: Use the weights to obtain scores for the different options and make a provisional decision atau gunakan bobot untuk mendapatkan skor untuk pilihan yang berbeda dan membuat keputusan povisional.

Menghitung Consistency Indexengan rumus : $\mathbf{C I}=(\boldsymbol{\lambda} \max -\mathbf{n}) / \mathbf{n}-\mathbf{1}$

Dimana :

CI : Consistensy Index

$\lambda \max :$ Eigen Value

$\mathrm{n} \quad$ : Banyak elemen

Menghitung Consistency Ratiodengan rumus :

\section{$\mathbf{C R}=\mathbf{C I} / \mathbf{R C}$}

Dimana :

CR : Consistency Ratio

CI : Consistency Index

RC : Random Consistency

Tabel 4. Nilai Rata-Rata Konsistensi

\begin{tabular}{cc}
\hline $\begin{array}{c}\text { Ukuran } \\
\text { Matriks }\end{array}$ & $\begin{array}{c}\text { Konsistensi } \\
\text { Acak }\end{array}$ \\
\hline 1 & 0,00 \\
2 & 0,00 \\
3 & 0,58 \\
4 & 0,90 \\
5 & 1,12 \\
6 & 1,24 \\
7 & 1,32 \\
8 & 1,41 \\
9 & 1,45 \\
10 & 1,49 \\
11 & 1,51 \\
12 & 1,54 \\
13 & 1.56 \\
14 & 1,57 \\
15 & 1,58 \\
\hline
\end{tabular}

Sumber : Saaty, 2000

\section{HASIL DAN PEMBAHASAN}

\section{Hasil Penelitian}

Tahapan Awal Pemilihan Jasa Forwarder

Dari data yang penulis dapatkan melalui depth interview dengan Departement Purchasing, berikut tahapannya :

1. Penawaran diri atau diundang untuk mengikuti bidding(lelang) melalui email.

2. Review Company Profile 
Ambar Wulan \& Bambang, analisis pemilihan jasa forwarder dengan menggunakan metode ...

3. Interview calon forwarder

4. Diskusi Divisi Internal

5. Proses Hiring dan Penandatangan Kontrak

Kriteria dan Sub-Kriteria Penilaian Jasa Forwarder

Kriteria penilaian jasa forwarder merupakan kriteria yang telah ditetapkan oleh PT. XYZ untuk menetapkan forwardermana yang akan dipilih nantinya.Kriteria tersebut adalah sebagai berikut :

Tabel 5. Kriteria Pemilihan Jasa Forwarder

\begin{tabular}{|l|l|}
\hline \multicolumn{1}{|c|}{ Kriteria } & \multicolumn{1}{c|}{ Pengertian } \\
\hline Cost & Biaya yang ditawarkan \\
\hline Quality & Kualitas yang ditawarkan \\
\hline Delivery & Jasa pengantaran yang dijanjikan \\
\hline Responsiveness & Respon cepat yang diberikan \\
\hline
\end{tabular}

Sumber :PT. XYZ (2016)

Tabel 6. Sub-Kriteria Pemilihan Jasa Forwarder

\begin{tabular}{|l|l|l|}
\hline No & Kriteria & Sub-Kriteria \\
\hline 1 & Cost & $\begin{array}{l}\text { Biaya pengiriman } \\
\text { Masa tenggang pembayaran } \\
\text { yang ditawarkan } \\
\text { Credit Limit yang ditawarkan }\end{array}$ \\
\hline 2 & Quality & $\begin{array}{l}\text { Memenuhi spesifikasi } \\
\text { pengiriman yang ditetapkan } \\
\text { Garansi terhadap material yang } \\
\text { dikirim }\end{array}$ \\
\hline 3 & Delivery & $\begin{array}{l}\text { Ketepatan pengiriman sesuai } \\
\text { waktu yang dijanjikan } \\
\text { Ketepatan waktu penjemputan } \\
\text { material }\end{array}$ \\
\hline 4 & Responsiveness & $\begin{array}{l}\text { Ketersediaan sistem informasi } \\
\text { Kemampuan merespon } \\
\text { permintaan pelanggan }\end{array}$ \\
\hline
\end{tabular}

Sumber :PT. XYZ (2016)

\section{Sub-Kriteria Cost}

Biaya pengiriman adalah biaya yang harus dikeluarkan oleh perusahaan dalam menggunakan suatu jasa forwarder. Perusahaan biasanya akan memilih forwarder yang menawarkan biaya pengiriman yang paling murah. Namun tidak menutup kemungkinan harga yang murah tersebut tidak diikuti dengan quality, delivery, dan responsiveness yang bagus pula.
Masa tenggang pembayaran adalah waktu tunda pembayaran akan jasa pengiriman yang ditawarkan oleh forwarder kepada pihak perusahaan.

Credit Limit adalah berapa batas hutang yang ditentukan oleh jasa forwarder kepada perusahaan. Beda forwarder beda pula batas hutang yang ditawarkan.

\section{Kriteria Quality}

Memenuhi spesifikasi pengiriman sebenarnya tergantung projectapa yang sedang dijalankan oleh perusahaan. Tidak bisa dipastikan spesifikasi khusus seperti apa. Namun spesifikasi pada umumnya hanya sebatas material jenis apa yang akan diangkat, didatangkan dari negara mana, jumlahnya berapa dan beratnya berapa.

Garansi terhadap material adalah garansi yang ditawarkan apabila dalam pengiriman material keperusahaan, terjadi kecelakaan atau kesalahan teknis. Namun pada implementasinya, garansi yang ditawarkan tidak sepenuh harga barang yang dikirim, berdasarkan data yang penulis dapatkan, garansi yang diberikan hanya sebesar biaya pengiriman akan suatu material saja. Tidak utuh seharga material yang diangkat. Karena para forwarder memegang suatu hak yang disebut sebagai perjanjian internasional/kontrak yang tidak mengharuskan mereka membayar utuh jika terjadi musibah yang tidak diinginkan.

\section{Kriteria Delivery}

Ketepatan pengiriman adalah ketepatan forwarder dalam mengantarkan material yang telah dijemput sebelumnya keperusahaan. Ketepatan adalah komitmen yang telah

disepakati sebelumnya dengan pihak perusahaan. Rencana akan pemakaian suatu material juga sudah ditetapkan. Jadi apabila komitmen itu dilanggar, maka rencana perusahaan tidak dapat terealisasi dengan baik.

Ketepatan akan waktu penjemputan suatu material tidak dibatasi oleh perusahaan, dengan kata lain fleksibel tergantung forwarder. Yang terpenting bagi perusahaan adalah material sampai diperusahaan tepat waktu. 


\section{Kriteria Responsiveness}

Bagi perusahaan sistem hanyalah sebuah sarana pendukung yang pada umumnya standart seperti website, yang bisa diakses oleh perusahaan untuk menyampaikan kritik dan saran untuk direspon oleh pihak forwarder.

Pelanggan adalah perusahaan itu sendiri. Kemampuan merespon permintaan pelanggan menjadi hal yang penting dalam memilih jasa forwarder. Dengan adanya respon yang cepat dan penanggulangan yang tepat dapat mempersingkat waktu pengiriman. Itulah mengapa respon menjadi hal yang lebih penting dibandingkan ketersediaan sistem informasi.

\section{Menyusun Struktur Hierarki}

Kriteria dan sub-kriteria serta caloncalon forwarder yang akan dipilih harus disusun dalam sebuah susunan hierarki guna memperoleh tingkatan kepentingan dalam bentuk penilaian kualitatif. Tujuan dari struktur hierarki adalah untuk menyusun masalahmasalah agar lebih terstruktur secara rapi dan dapat dimengerti.

Berdasarkan data yang diperoleh dari wawancara dengan karyawan PT. XYZ, maka dapat digambarkan suatu susunan hierarki sebagai berikut : 
Ambar Wulan \& Bambang, analisis pemilihan jasa forwarder dengan menggunakan metode ...

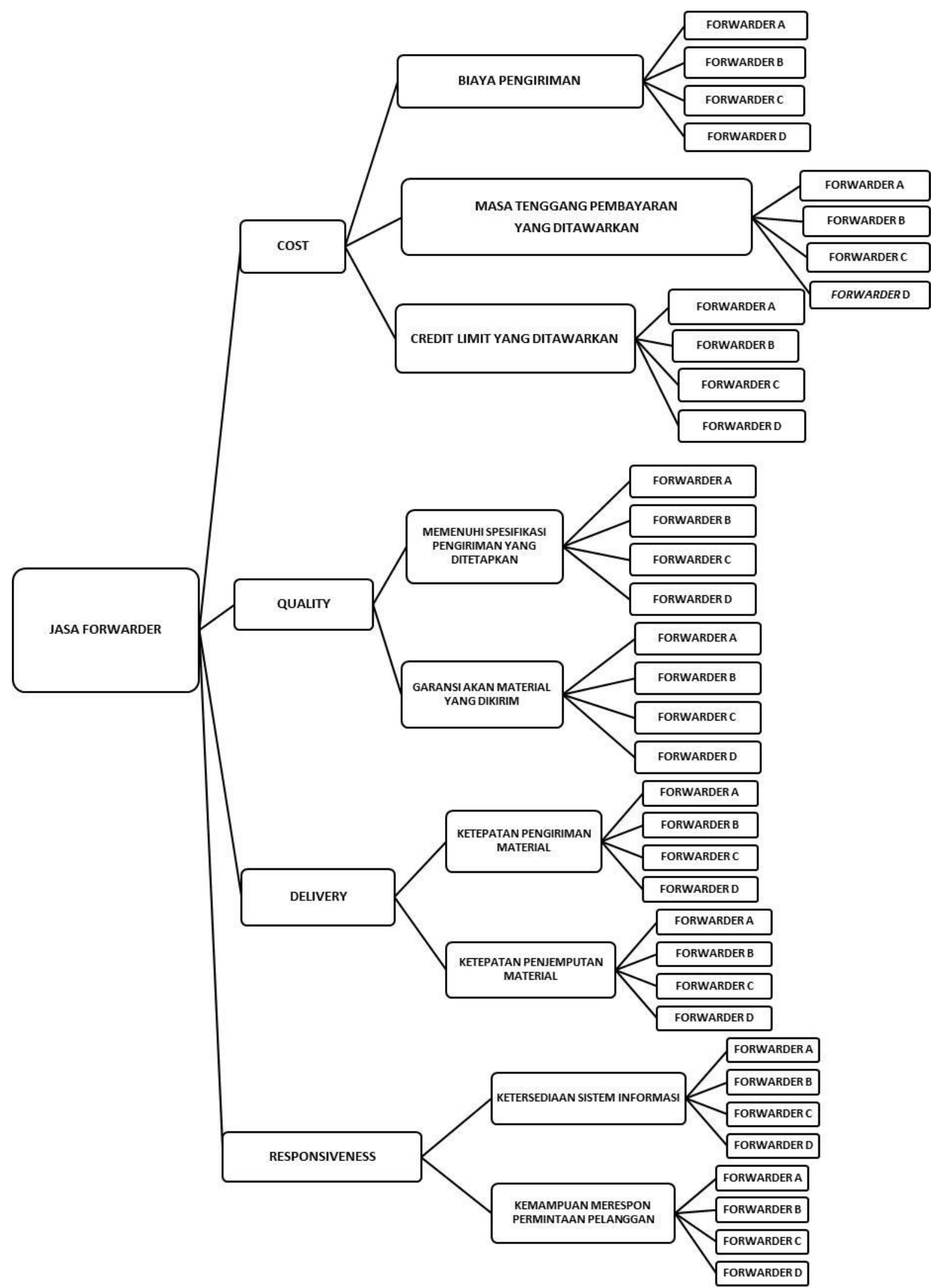

Gambar 2. Struktur Hierarki

Sumber : Hasil Olah Data, 2016 
Journal of Applied Business Administration Vol 2, No 2,September 2018, hlm. 294-306

\section{Analisa Bobot Kriteria Dan Sub-Kriteria}

Tabel 7. Bobot Kriteria

\begin{tabular}{|l|c|c|c|}
\hline \multicolumn{1}{|c|}{ Kriteria } & Bobot & Persentase & Peringkat \\
\hline Cost & 0.484135 & $48 \%$ & 1 \\
\hline Quality & 0.23109 & $23 \%$ & 2 \\
\hline Delivery & 0.167628 & $17 \%$ & 3 \\
\hline Responsiveness & 0.117147 & $12 \%$ & 4 \\
\hline
\end{tabular}

Sumber : Hasil Olah Data, 2016

Kriteria Cost menduduki peringkat pertama, hal ini dikarenakan sebagai perusahaan harus sebisa mungkin meminalisir biaya pengeluaran agar dapt digunakan untuk keperluan lainnya dan terkait kepada cost-saving perusahaan.

Walaupun kiteria cost mendapat peringkat yang pertama dalam penelitian ini, namun tidak bisa dipastikan forwarder yang menawarkan harga yang termurah yang akan dipilih, karena masih ada kriteria quality dan delivery yang akan menjadi bahan penilaian kedepannya.

Karena bagi perusahaan, quality, delivery dan responsiveness suatu forwarder itu tak kalah penting bagi kelangsungan proses pengiriman material keperusahaan.

Tabel 8. Bobot Sub-Kriteria

\begin{tabular}{|l|l|c|}
\hline Sub-Kriteria & \multicolumn{1}{|c|}{$\begin{array}{c}\text { Bobot } \\
\text { Lokal }\end{array}$} & $\begin{array}{c}\text { Bobot } \\
\text { Global }\end{array}$ \\
\hline $\begin{array}{l}\text { Biaya } \\
\text { Pengiriman }\end{array}$ & 0.588888889 & 0.285101496 \\
\hline $\begin{array}{l}\text { Masa tenggang } \\
\text { pembayaran yang } \\
\text { ditawarkan }\end{array}$ & 0.251851852 & 0.121930199 \\
\hline $\begin{array}{l}\text { Credit Limit yang } \\
\text { ditawarkan }\end{array}$ & 0.159259259 & 0.07710292 \\
\hline $\begin{array}{l}\text { Memenuhi } \\
\text { spesifikasi } \\
\text { pengiriman yang } \\
\text { ditetapkan }\end{array}$ & 0.833333333 & 0.192574786 \\
\hline $\begin{array}{l}\text { Garansi terhadap } \\
\text { material yang } \\
\text { dikirim }\end{array}$ & 0.166666667 & 0.038514957 \\
\hline $\begin{array}{l}\text { Ketepatan } \\
\text { pengiriman waktu } \\
\text { sesuai } \\
\text { yang dijanjikan }\end{array}$ & 0.833333333 & 0.139690171 \\
\hline $\begin{array}{l}\text { Ketepatan waktu } \\
\text { penjemputan }\end{array}$ & 0.166666667 & 0.027938034 \\
\hline
\end{tabular}

\begin{tabular}{|l|c|c|}
\hline \multicolumn{1}{|c|}{ Sub-Kriteria } & $\begin{array}{c}\text { Bobot } \\
\text { Lokal }\end{array}$ & $\begin{array}{c}\text { Bobot } \\
\text { Global }\end{array}$ \\
\hline material & & \\
\hline $\begin{array}{l}\text { Ketersediaan } \\
\text { sistem informasi }\end{array}$ & 0.166666667 & 0.019524573 \\
\hline $\begin{array}{l}\text { Kemampuan } \\
\text { merespon } \\
\text { permintaan } \\
\text { pelanggan }\end{array}$ & 0.833333333 & 0.097622863 \\
\hline & & $\mathbf{1 . 0}$ \\
\hline
\end{tabular}

Sumber : Hasil Olah Data, 2016

Dari tabel 8 bisa dilihat hasil dari perhitungan metode AHP dengan menggunakan softwareExpert. Choice v.11, sub-kriteria Cost (Biaya Pengiriman) mendapat bobot tertinggi. Hal ini dikarenakan terkait ketetapan yang menginginkan biaya pengiriman yang murah untuk suatu forwarder. Namun jika perusahaan tetap memilih forwarder dengan harga yang rendah, maka perusahaan juga akan mendapat forwarder dengan quality, delivery, dan responsiveness yang rendah pula. Disini perusahaan perlu mempertimbangkan benarbenar keputusannya.

Diperingkat kedua yaitu sub-kriteria Quality (Memenuhi Spesifikasi Pengiriman

Yang Ditetapkan). Bagi perusahaan suatuforwarderharus bisa memenuhi spesifikasi yang ditetapkan, karena bagi perusahaan itu adalah sebuah komitmen yang harus dilaksanakan.

Lalu diperingkat ketiga ada sub-kriteria Delivery(Ketepatan Pengiriman Material). Bagi perusahan ketepatan menjadi poin penating, karena berhubungan dengan perencanaan penggunaan material dan proses produktivitas. Keterlambatan dalam proses pengiriman akan berdampak tidak baik bagi perusahaan.

\section{Analisis Bobot Jasa Forwarder}

Berdasarkan kriteria dan sub-kriteria yang telah ditetapkan oleh PT. XYZ, forwarder yang dipilih pada penelitian ini hanyalah forwarderforwarder yang mengikuti bidding di PT. XYZ. Berdasarkan hasil perhitungan dengan 
Ambar Wulan \& Bambang, analisis pemilihan jasa forwarder dengan menggunakan metode ...

softwareExpert. Choice v.11, maka hasil bobot untuk setiap forwarder adalah sebagai berikut :

Tabel 9. Bobot Keseluruhan Forwarder

\begin{tabular}{|c|c|c|c|}
\hline Forwarder & Bobot & Persentase & Peringkat \\
\hline $\begin{array}{c}\text { Forwarder } \\
\text { A }\end{array}$ & 0.535 & $53 \%$ & 1 \\
\hline $\begin{array}{c}\text { Forwarder } \\
\text { B }\end{array}$ & 0.202 & $20 \%$ & 2 \\
\hline $\begin{array}{c}\text { Forwarder } \\
\text { C }\end{array}$ & 0.145 & $15 \%$ & 3 \\
\hline $\begin{array}{c}\text { Forwarder } \\
\text { D }\end{array}$ & 0.119 & $12 \%$ & 4 \\
\hline
\end{tabular}

Sumber : Hasil Olah Data, 2016

Tabel 9 memperlihatkan bobot keseluruhan yang diperoleh masing-masing forwarder. Karena peringkat teringgi dipegang oleh forwarder A dengan bobot sebesar 0.535 , maka seharusya PT. XYZ memilih forwarder A untuk menjalin kerjasama kedepannya.

\section{SIMPULAN DAN SARAN Kesimpulan}

Berdasarkan hasil penelitian terkait pemilihan jasa forwarder dengan menggunakan metode Analytical Hierarchy Process (AHP) di PT. XYZ, maka kesimpulan yang didapat adalah sebagai berikut :

1. Sebelum memilih jasa forwarder yang dinginkan, PT. XYZ telah memiliki kriteria tersendiri untuk memudahkan proses pemilihan. Kriteria-kriteria tersebut adalah

Cost, Quality, Delivery, dan Responsivenessdan juga 9 ketetapan subkriteria. Yaitu 3 sub kriteria untuk kriteria Cost, 2 sub kriteria untuk kriteria Quality, 2 sub-kriteria untuk kriteria Delivery, dan 2 sub-kriteria untuk kriteria Responsiveness.

2. Kriteria yang paling memberikan kontribusi terhadap pemilihan jasa forwarder di PT. XYZ adalah Cost diperingkat pertama dengan bobot tertinggi sebesar 0.484134615 . Kemudian Quality diperingkat kedua dengan bobot sebesar 0.231089744. Lalu Delivery diperingkat ketiga dengan bobot sebesar 0.167628205dan kriteria Responsiveness diperingkat terakhir dengan bobot terendah yaitu hanya 0.117147436 . Kriteria dengan bobot yang paling tinggi adalah kriteria yang paling penting.

3. Alternatif pemilihan jasa forwarder yang paling tepat untuk PT. XYZ adalah Forwarder A dengan bobot keseluruhan sebesar 0.535, Forwarder B dengan bobot keseluruhan sebesar 0.202, Forwarder $\mathrm{C}$ dengan bobot keseluruhan sebesar 0.145, dan Forwarder D dengan bobot keseluruhan hanya sebesar 0.119 .

\section{Saran}

Berdasarkan hasil penelitian yang peneliti lakukan terkait jasa pemilihan forwarder, berikut saran dari penulis :

1. Perusahaan seharusnya juga mementingkan

kriteria Quality, Delivery dan

Responsiveness juga. Karena jika hanya berpatokan pada kriteria Cost, dan mementingkan Cost yang murah yang ditawarkan, maka perusahaan tidak akan mendapat Quality, Delivery dan Responsiveness yang bagus.

2. Perusahaan dapat memilih jasa forwarderA karena hasil perhitungan forwarder A memiliki bobot tertinggi untuk semua kriteria yang dibutuhkan perusahaan secara keseluruhan.

3. Perusahaan seharusnnya melakukan penelitian yang komprehensif menggunakan metode AHP karena berdasarkan AHP, forwarder yang terbaik bagi perusahaan adalah forwarder $\mathrm{A}$.

\section{DAFTAR PUSTAKA}

Goodwin, Paul \& George Wright, 2004, Decision Analysis for managementJudgement $3^{\text {rd }}$ Edition, Copyright $@ 2004$. John Wiley \& Sons

Ltd, The Atrium, Southern Gate, Chichester, West Sussex PO19 8SQ, England.

Ismanthono, Henricus W., 2010, Kamus Istilah Ekonomi dan Bisnis, Agustus Penerbit PT KompasMedia

Nusantara, Jakarta. 
Journal of Applied Business Administration Vol 2, No 2,September 2018, hlm. 294-306

Jannah, Miftakhul, Muhammad Fakhry, dan

Rahmawati, 2011, Pengambilan

Keputusan Untuk Pemilihan

Supplier Bahan Baku Dengan

Pendekatan Analytic Hierarchy

Process Di PR Pahala Sidoarjo, Jurnal

AGROINTEK, Vol. 5, No. 2, Agustus

2011. Diakses 18 February 2016, 21:30.

Kartikasari, Dwi, 2008, Penelitian Dasar

Pengembangan Komoditi Unggulan

Usaha Mikro Keci dan Menengah

(UMKM) Provinsi Kepulauan Riau.

Kasmawaty, Desty, 2015, Evaluasi Kinerja Supplier Dengan Menggunakan Metode Analytical Hirarchy Process (AHP), Skripsi Politeknik Negeri Batam, Jurusan

Manajemen Bisnis, Program Studi D4 Administrasi Bisnis Terapan, 2015.

Mwikali, Ruth, Stanley Kavale, 2012, Factors

Affecting the Selection of Optimal

Suppliers in Procurement

Management, International Journal of Humanities and Social Science, Vol. 2 No.14 [Special Issue - July 2012]. Diakses tanggal 2 Febrauri 2016, 23:03

Prasetya, Hery dan Fitri Lukiastuti, 2009, Manajemen Operasi, Penerbit PT. BUKU KITA, Jakarta.

Saaty, Thomas L., 2000, Fundamentals of decision making and priority theory with the analytical hierarchy process, $6^{\text {th }}$ volume of AHP Series, Pittsburgh, PA RWS Publications, (C)2000, (e-book http://www.worldcat.org/title/fund ntal-of-decision-making-and-priority theory-with-the-analytic-hierarchy process/oclc/45161976. Diakses tanggal

$8 \quad$ Februari 2016, 16:10.

Samekto, Agus Aji dan Soejanto, 2014, Meningkatkan Kinerja Perusahaan Ekspedisi Muatan Kapal Laut Melalui Diversifikasi Usaha, Jurnal
Manajemen Transportasi dan Logistik (JMTRANSLOG), Vol. 1 No.1. Diakses tanggal $14 \quad$ Maret, 20:13

Satori, Djam'an, dan Aan Komariah, C2011, Metodologi Penelitian Kualitatif, Alfabeta, Bandung.

Siswosoediro, Henry S., 2008, Buku Pintar Pengurusan Perizinan \& Dokumen, Penerbit Transmedia Pustaka, Jakarta Selatan.

Sugiarto, dkk, 2002, Ekonomi Mikro Sebuah Kajian Komprehensif, Penerbit PT Gramedia Pustaka Utama, Jakarta. Sugiyono, 2014, Metode Penelitian Kuantitatif, Kualitatif, dan R\&D, Penerbit Alfabeta CV, Bandung.

Sugiyono, 2015, Metode Penelitian Manajemen, Penerbit Alfabeta CV, Bandung.

Rajasekar dan Prabhakar, 2015, Importance of Freight Forwarding and Work Activities of Freight Forwadere-an Empirical Analysis,Indian Journal of Apllied Research. Volume : 5 Issue : 1 Jan 2015 ISSN - 2249-555x

Tominanto, 2013, Sistem Pendukung Keputusan Dengan Metode Analytical Hierarchy Process (AHP) Untuk Penetuan Prestasi Kinerja

Dokter Pada RSUD. Sukoharjo, Jurnal Ilmiah Rekam Medis dan Informatika Kesehatan, VOL. 2 NO. 1,ISSN :20862628. Diakses pada tanggal 4 Februari 2016, 21:40

Waluyo, 2008, Akuntansi Pajak, Penerbit Salemba Empat, Jakarta.

Wardah,Siti, 2013, Model Pemilihan Pemasok Bahan Baku Kelapa Parut Kering Dengan Metode AHP (Studi Kasus PT. Kokonako Indonesia), Jurnal Optimasi Sistem Industri, 
Ambar Wulan \& Bambang, analisis pemilihan jasa forwarder dengan menggunakan metode ...

Vol. 12 No. 2, ISSN 2088-4842. Diakses

pada tanggal 2 Februari 2016, 23:04

Wibowo, Agung Edy, 2012, AplikasiPraktis SPSS dalam Penelitian, Penerbit Gava Media, Yogyakarta.

Yuliana, Rahmi, 2012, Analisis Pengaruh StrategiServiceRecovery Yang Dilakukan Perbankan Terhadap Kepuasan Nasabah Di Kota Semarang, Jurnal STIE Semarang, Vol 4, No 2, Edisi Juni 2012, (ISSN : 2252_7826. Diakses tanggal 18 Februari 2016, 21:17. 